\title{
9. Listening to Heavy Metal in Wadeye
}

\author{
John Mansfield
}

\section{Introduction}

Most of the chapters in this volume examine how Aboriginal cultural artefacts have travelled outwards from their places of origin, being distributed, deployed or displaced in distant social contexts. This chapter treats the inverse situation: how a cultural product that has its origins in Europe and North America has been received and re-used in an Aboriginal town of tropical northern Australia. The cultural product in question is heavy metal-primarily a musical genre, which first emerged in Britain and the US in the 1980s, but also an associated array of images, texts and fashion statements. ${ }^{1}$ The site of reception is Wadeye, Australia's largest remote Aboriginal town, with a population of some 2,500 people, whose antecedents moved in to settle the Port Keats Mission in the midtwentieth century. In 1975 the Mission was dissolved, and the newly secular town renamed as Wadeye. ${ }^{2}$ Since the late-1980s the youth have become avid fans of heavy metal, though the extensive equipment required for producing heavy metal music has prevented any metal bands from forming in Wadeye. The music has come to be associated with public disorder and what the media describe as 'heavy metal gangs' ${ }^{3}$ The popularity of metal in Wadeye tends to arouse great curiosity among visitors, presumably because metal is reflexively associated with urban or suburban settings, while Wadeye is an isolated town some 400 kilometres from the larger urban centres of Darwin and Katherine.

My analysis of heavy metal in Wadeye focuses on social practices and the material objects that facilitate them. My primary aim is to examine the social contexts in which Wadeye youth listen to heavy metal, share and distribute metal, talk about metal, wear, dance, draw and graffiti metal, based on some fifteen months of fieldwork I conducted during 2011-2013. Secondarily, I use these empirical observations to analyse what metal might mean to those who listen to it in Wadeye. I aim to provide a brief but holistic account of how

1 Ian Christie, Sound of the Beast: The complete headbanging history of heavy metal (New York: Harper Collins, 2003). 2 Br John MSC Pye, The Port Keats Story (Darwin: Colemans, 1972); 'The Port Keats Story: Part Two.' unpublished ms; accessed at Wadeye community archive, n.d.

3 Lindsay Murdoch, 'Hate Stalks a Community Where Gangs Rule Roost', The Age, 23 May 2006; Hannah Brooks and Jonathan West, Heavy Metal Gangs of Wadeye (VBS, 2009); Paul Toohey, 'Gangsters' Paradise', Bulletin, 10 February 2004. 
metal culture has been adopted at Wadeye, and in doing so I hope to expose a productive intersection between media studies and the anthropology of cultural diffusion. The first section of the chapter reviews previous scholarship that I consider most relevant to such an intersection.

The transmission of heavy metal to Wadeye first occurred by means of music video programming, which began appearing in television broadcasts from about 1987. Cassettes and later CDs allowed favourite recordings to be played repeatedly, and fandom became established, with band allegiances giving rise to the social groupings that have been previously labelled heavy metal 'gangs', though I prefer the term 'mobs' . ${ }^{4}$ More recently, mobile phones have become at least as important in listening to and distributing heavy metal music at Wadeye, while graphic elements of heavy metal culture also circulate as graffiti and fashion. The second section of this chapter describes the main ways in which heavy metal cultural artefacts circulate in Wadeye, as material technologies distributed through social interactions. The section summarises as much as can be reconstructed about the early period of metal in Wadeye, while giving more detail on recent practices that I have observed in my fieldwork during 2011.

The third section of this chapter draws on the observations of the previous section to develop an analysis of what heavy metal means to the young men of Wadeye. This is by necessity a more interpretive task, and does not purport to be exhaustive or exclusive of contrasting interpretations. However, by situating meaning within social observable practices, this analysis does aim to have a somewhat objective basis. The section is structured around two particular social interactions, which are used as spring-boards for discussing the meaning of heavy metal in Wadeye more widely. The first of these interactions is a series of group dances held at a 'heavy metal disco' that I did not observe directly but rather saw in a documentary filmed in $2008 .^{5}$ The dance event reflects a series of related concepts: brotherhood, consubstantiality, spirit beings, power, subversion and evil, and these concepts are evidently developed in other social practices at Wadeye. The second interaction was one I observed directly, a fleeting moment in which one local made an unselfconscious comment about heavy metal to another. But the comment references a conceptual opposition between 'blackfella' and 'whitefella', which can be seen as an unresolved tension in the meaning of heavy metal at Wadeye.

Though this chapter deals with Aboriginal reception of whitefella culture, rather than whitefella reception of Aboriginal culture, it is like other chapters in the book an instance of 'transformation of the meanings with which cultural

\footnotetext{
4 John Mansfield, 'The Social Organisation of Wadeye's Heavy Metal Mobs', The Australian Journal of Anthropology 24:2 (2013):156.

5 Brooks and West, Heavy Metal Gangs of Wadeye.
} 
objects are imbued'. ${ }^{6}$ The moral, spiritual and symbolic dimensions that metal takes on in Wadeye are only obliquely related to the meanings it bears in its sites of origin.

\section{Aboriginal Adoption of Foreign Cultural Materials}

There is a considerable body of work discussing how foreign cultural influences have been absorbed and modified by Aboriginal people, and a rather smaller range of studies that examine Aboriginal reception of mass media. Probably the most researched topic in the former category is the introduction of Christianity among Aboriginal people, ${ }^{7}$ although Sutton has also examined the adoption of New Age spirituality. ${ }^{8}$ Most other studies of cultural adoption deal with material culture such as mass-produced alcohol, cash, vehicles, houses, playing cards, and digital information devices. ${ }^{9}$

With regards to the reception of mass media there are a few notable studies, though the area has not been widely researched, and there is rather more work on Aboriginal people as media producers. ${ }^{10}$ Michaels' work on television

\footnotetext{
6 Harris, Chapter 1, this volume.

7 Fiona Magowan, 'Faith and Fear in Aboriginal Christianity', in Aboriginal Religions in Australia: An anthropology of recent writings, eds M. Charlesworth, Francoise Dussart, and Howard Morphy (Aldershot: Ashgate, 2005), 279-96; R. Tonkinson, 'Reflections on a Failed Crusade', in Aboriginal Australians and Christian Missions, eds T. Swain and Deborah Bird Rose (Bedford Park: Australian Association for the Study of Religions, 1988), 60-73; 'Christianity in Aboriginal Australia Revisited', The Australian Journal of Anthropology 21 (2010): 1-13.

8 Peter Sutton, 'Aboriginal Spirituality in a New Age', The Australian Journal of Anthropology 21 (2010): 71-89.

9 Alcohol: M. Brady, Heavy Metal: The social meaning of petrol sniffing in Australia (Canberra: Aboriginal Studies Press, 1992); Basil Sansom, The Camp at Wallaby Cross: Aboriginal fringe dwellers in Darwin (Canberra: Australian Institute of Aboriginal Studies, 1980); David McKnight, From Hunting to Drinking: The devastating effects of alcohol on an Australian Aboriginal community (London: Routledge, 2002). Cash: Basil Sansom, 'A Grammar of Exchange', in Being Black: Aboriginal cultures in 'settled' Australia, ed. Ian Keen (Canberra: Australian Institute of Aboriginal Studies, 1988), 159-78; Nicolas Peterson, 'Cash, Commoditisation and Authenticity: When do Aboriginal people stop being hunter-gatherers? In Cash, Commoditisation and Changing Foragers, eds Nicolas Peterson and Toshio Matsuyama (Osaka: National Museum of Ethnology, 1991), 67-90. Vehicles: John Altman and Melinda Hinkson, 'Mobility and Modernity in Arnhem Land: The social use of Kuninjku trucks', Journal of Material Culture 12:2 (2007): 181-203; Glenn Dawes, 'Figure Eights, Spin Outs and Power Slides: Aboriginal and Torres Strait Islander youth and the culture of joyriding', Journal of Youth Studies 5:2 (2002): 195-208. Houses: Yasmine Musharbash, Yuendumu Everyday: Contemporary life in a remote Aboriginal settlement (Canberra: Aboriginal Studies Press, 2008). Playing cards: John Altman, HunterGatherers Today: An Aboriginal economy in northern Australia (Canberra: Aboriginal Studies Press, 1987); David Fernandes Martin, Autonomy and Relatedness: An ethnography of Wik people of Aurukun, Western Cape York Penninsula (PhD, The Australian National University, 1993), 115-35. Digital devices: Inge Kral, Plugged in: Remote Australian Indigenous youth and digital culture (Canberra: CAEPR, 2010).

10 Eric Michaels, The Aboriginal Invention of Television in Central Australia, 1982-1986 (Canberra: Australian Institute of Aboriginal Studies, 1986); Wendy Bell, A Remote Possibility: The battle for Imparja television (Alice Springs: IAD Press, 2008); Jennifer Deger, Shimmering Screens: Making media in an Aboriginal community (University of Minnesota Press, 2006); Heather Molnar and Michael Meadows, Songlines to Satellites: Indigenous communication in Australia, the South Pacific and Canada (Sydney and Wellington: Pluto Press and Huia Publishers, 2001).
} 
production among the Warlpiri is deservedly celebrated, though he also makes some valuable observations on Warlpiri viewing practices of Hollywood videos in the days before television broadcasts began. According to Michaels, Warlpiri viewers pay less attention than Western audiences to the matter of fictional characters' motivations, but instead take a great interest in the kin relationships at work in the film - which they find to be much under-specified.

When Hollywood videos fail to say where Rocky's grandmother is, or who's taking care of his sister-in-law, Warlpiri viewers discuss the matter and need to fill in the missing content. ${ }^{11}$

From the 1950s until the 1980s, Hollywood films were watched by the Warlpiri at film nights in the community dining room. These gatherings were somewhat problematic in that they created inappropriate conjunctions of taboo kin relations in the shared space. This was resolved in the 1980s when film viewing switched to VCR videos, which could be viewed by smaller groups in private homesthough the upkeep of video equipment in the dusty desert environment proved very expensive. ${ }^{12}$ There were evidently communal film nights in many remote Aboriginal communities - Wadeye had them from the 1960s - which in general gave way to video in the 1980s. Scattered references attest to a preference for action and kung-fu movies, ${ }^{13}$ which might be related to the fact that these can be easily followed without needing to comprehend English dialogue.

In the realm of mass-mediated popular music, the Aboriginal reception of two particular genres has been described: country music and hip-hop. Country music is much loved by older Aboriginal men across central and northern Australia, especially those who have worked in the cattle industry. Brown describes how the country music of Slim Dusty and Charley Pride was played alongside local ceremonial music as part of a burial rite at Gunbalanya. ${ }^{14}$ Ottosson gives particular attention to the social events at which Aboriginal people play and listen to country music, how they evaluate musicianship and determine band membership. ${ }^{15}$ She argues that Aboriginal understanding of country music is linked to concepts of legitimate masculinity, and emotive relations with the land.

11 Eric Michaels, 'Hollywood Iconography: A Warlpiri reading', in Second International Television Studies Conference, 1986, eds Phillip Drummond and Richard Patterson (London : BFI Publishing, 1988), 119.

12 Michaels, The Aboriginal Invention of Television in Central Australia, 1982-1986, 37-45.

13 Brady, Heavy Metal, 89; McKnight, From Hunting to Drinking, 101, 222.

14 Brown, this volume.

15 Ase Ottosson, 'The Intercultural Crafting of Real Aboriginal Country and Manhood in Central Australia', The Australian Journal of Anthropology 23 (2012): 179-96; Alberto Furlan, Songs of Continuity and Change: The reproduction of Aboriginal culture through traditional and popular music (PhD, University of Sydney, 2005), 217-22. 
The reception and production of hip-hop has been described with respect to urban Aboriginal people, ${ }^{16}$ and though anecdotal evidence suggests that it is also very popular in some remote areas, it has not been studied in the latter context. The works on urban Aboriginal hip-hop all argue that hip-hop is an authentic and local Aboriginal cultural form, not just a copy of something 'foreign'. Indeed Pennycook and Mitchell maintain that hip-hop is 'a continuation of Indigenous traditions', arguing that it is authentically Aboriginal because it renews a timeless tradition of transmitting culture by song and dance. ${ }^{17}$

In the description that follows I do not attempt to define heavy metal at Wadeye as authentically local, though neither do I consider it to be a corruption of local culture by foreign influence. Culture is always diffuse and always in the process of diffusion; particular forms adhere to social and geographic localities, but are always sliding down a spectrum from the foreign to the autochthonous to the forgotten. Trying to place things on this spectrum seems far less productive than identifying the social practices and interactions through which a cultural import is integrated, and examining how it might contribute to 'the structures of meaning through which [people] give shape to their experience' ${ }^{18}$

\section{Heavy Metal in Wadeye: Material Technologies and Social Exchange}

Heavy metal is essentially an extreme version of rock music, which emerged in the 1980s when its precursors, 'hard rock' and 'glam rock', tried to outdo each other in rock'n'roll extravagance. ${ }^{19}$ Metal is characterised by loud, insistent, distorted guitars and vocals that tend towards wailing or growling. It is a music of strident machismo, in contrast to disco and punk, two late-70s genres against which metal rebelled. ${ }^{20}$ Metal also contrasts with punk in being highly concerned with complex musicianship. In the course of the 1980s metal was transformed from a commercially insignificant genre limited to certain cities

\footnotetext{
16 George Morgan and Andrew Warren, 'Aboriginal Youth, Hip Hop and the Politics of Identification', Ethnic and Racial Studies 34:6 (2011): 925-47; Alastair Pennycook and Tony Mitchell, 'Hip Hop as Dusty Foot Philosophy: Engaging locality', in Global Linguistic Flows: Hip hop cultures, youth identities and the politics of language, ed. H. Samy Alim, Awad Ibrahim, and Alistair Pennycook (New York: Routledge, 2009), 25-42; Tony Mitchell, 'Blackfellas Rapping, Breaking and Writing: A short history of Aboriginal hip-hop', Aboriginal History 30 (2006): 124-37.

17 Pennycook and Mitchell ‘Hip Hop as Dusty Foot Philosophy': 35.

18 Clifford Geertz, The Interpretation of Cultures (New York: Basic Books, 1973), 312.

19 Christie, Sound of the Beast.

20 Steve Waksman, This Ain't the Summer of Love: Conflict and crossover in heavy metal and punk (Berkeley: University of California Press, 2009); Leigh Krenske and Jim McKay, "“Hard and Heavy": Gender and power in a heavy metal music subculture', Gender, Place and Culture 7:3 (2000): 287-304.
} 
in Britain and the US, to a globally successful cultural commodity. Bands that led this global conquest included Iron Maiden, Judas Priest, Def Leppard, and above all Metallica.

There is at least one exemplary study of how heavy metal culture has reached social contexts far from its origins, in Baulch's study of the Bali death metal scene. ${ }^{21}$ Baulch describes how death metal music was largely introduced to Bali via a single individual who imported cassette tapes, and was more generally a trendsetter in the scene. ${ }^{22}$ Much of what she reports of the Bali scene might apply to any death metal scene anywhere - for example the formation of local bands that initially imitate what they hear on recordings, or the sense of subcultural opposition to 'the mainstream' ${ }^{23}$ However, after some years the Bali death metal bands have begun to incorporate local melodies and mythology into the music. ${ }^{24}$

The use of heavy metal at Wadeye is rather different to what Baulch reports from Bali. For one thing, metal in Wadeye is not a 'scene' among the diverse musical subcultures of an urban environment; rather, it is a cultural form that has been taken on by the whole of the young male population, through forms of interaction and exchange quite distinct to those that might characterise urban metal culture. A more typical urban metal scene, focused on specific nightclubs and record shops, is described by Krenske and McKay, ${ }^{25}$ while the 'underground' scenes of death metal and black metal are described in Purcell ${ }^{26}$ and Murphy ${ }^{27}$ respectively. The young men of Wadeye are often blamed as a group for social unrest in the town, but there is no special disapproval or marginalisation associated with heavy metal. There are no distinctions involving different social groups following different sub-genres of metal, but rather a highly conventionalised metal fandom that is shared to some extent by all the young men. By contrast, older people in Wadeye dislike heavy metal music, while the young women, with whom I have not been able to do any ethnographic research due to local taboos against mixed-gender sociality, express affiliation to the metal social groupings of their brothers, but show less interest in the music itself.

\footnotetext{
21 Emma Baulch, Making Scenes: Reggae, punk, and death metal in 1990s Bali (Durham: Duke University Press, 2007).

22 ibid., 53-7.

23 ibid., $23,61$.

24 ibid., 161-70.

25 Krenske and McKay, “'Hard and Heavy"”.

26 Natalie J. Purcell, Death Metal Music: The passion and politics of a subculture (Jefferson: McFarland \& Company, 2003).

27 David Jo Murphy, Hate Couture: Subcultural fundamentalism and the Serbian black metal scene (PhD, NUI Maynooth, 2011).
} 


\section{The Arrival of Metal in Wadeye}

At a distance of some twenty-five years, it is difficult to trace with certainty how heavy metal first arrived in Wadeye, but much of the evidence points to Rage, the music video program that commenced broadcasting in 1987. It was at about the same time that the Broadcasting for Remote Aboriginal Communities Scheme - stimulated in large part by Michaels' collaborative work with Francis Jupurrurla at Yuendumu-commenced television broadcasts in dozens of remote Aboriginal towns, including Wadeye. ${ }^{28}$

In the late 1980s, heavy metal was one of the most commercially successful popular music genres, and its tendency towards extravagant visual spectacle was particularly well suited to the new medium of music videos. Indeed, the rise of heavy metal and rise of the music video format were substantially interdependent, ${ }^{29}$ and it seems that heavy metal music videos were among the most influential forms of content when television started broadcasting at Wadeye. Various Wadeye men have related to me how they first discovered their favourite metal bands on Rage, and how they would remember the band names so that they could buy cassettes, and later CDs, from Kmart on their next trip to Darwin. For example:

First hear television ngarra Rage. "Ah, I wanna be like that man! Ngamanu mangi kardu nimi-ka kanarntel, ini-ka. Nukunu-ka marda manganart kardu geng ini-ka, ngay-ka kanyi le nganam. Kardu pelpitj wiye, pemarr pangkuy." Yuwu, first-time ngay binyepup, ngay-ka mam "Nangkul pup? Ku bamam. Tjung patha kanyi," mam ne. Good songs. And I understand ngamam what it's about. Tjung ini ngarra war, war story kama mam. Tju murrinh story pumam.

I first heard [White Lion] on the television program Rage. "Ah, I wanna be like that man! I will be like that man singing, like that. I want to make my gang like him, this is something I like. A crazy man, with long hair." Yes, the first time I heard them, I said, "Who is this? A whitefella. This is a good song," I said. And I understood what it was about. That song was about war, maybe a war story. It was a fighting story. ${ }^{30}$

It is noticeable that the heavy metal bands most popular in Wadeye are in all cases commercially successful ones of the type that might be expected to be included in Rage programming (for example, Iron Maiden, Judas Priest, Metallica, Bullet for My Valentine), while bands of the more extreme, 'underground' metal subgenres such as death metal and black metal seem to be unknown at

28 Molnar and Meadows, Songlines to Satellites, 34.

29 Christie, Sound of the Beast, 77-83.

30 SL, aged 49; author's recording, 13 October 2011. 
Wadeye, presumably because they are too offensive to ever be included on Rage. Extreme metal subgenres first spread through fanzines and mail-order cassette networks, ${ }^{31}$ and more recently have been distributed predominantly through online networks. Neither of these types of media networks have much presence in Wadeye, where young men usually lack both literacy and computer access.

Perhaps the most noticeable impact of heavy metal in Wadeye was the fact that, soon after its introduction, kardu kigay (young men from teenage years through till their 30s) began to name their peer groups after metal bands. In news reports these groups have been labelled 'heavy metal gangs', though they are in fact kin groupings, generally connected by classificatory 'brother' (Br, MoZiSo, FaBrSo) or 'cousin' (MoBrSo, FaZiSo) relationships, and are in many ways dissimilar from urban gangs. Elsewhere I describe in detail how these 'metal mobs' are constituted by collateral kinship, and how this differs from the patrilineal kinship organisation of traditional clans. ${ }^{32}$ For the purposes of this chapter, it should suffice to note that heavy metal music in Wadeye is not just a matter of individual musical taste, but has taken on a major role in symbolising groups of kigay in the social arena. Every kigay can be identified by affiliation with one or more metal mobs, and the metal bands to which one affiliates are known as one's $k u$ spidi (from English 'speed metal'). Actual enjoyment of the music is not necessary for mob affiliation, which is in essence a form of social classification. However, many kigay do enjoy metal music, and often listen to it, though there are no local metal bands in Wadeye. The lack of any local metal music production is probably due to the lack of musical equipment (guitars, amplifiers, drum kits, etc.), of which heavy metal is quite demanding.

\section{Listening to Metal}

When a heavy metal band has been 'discovered' and a cassette or CD obtained, the next step is to play the music in Wadeye. The long-standing method for this is the home stereo system, which facilitates playing the music at high volume. Kigay of the same mob, or related mobs, gather in groups at any house that has a stereo system, and listen to metal together, often accompanied by the smoking of marijuana. Kigay say that the effect of marijuana goes well with heavy metal, and when a strong effect is obtained, they describe the experience as frikinet (from 'freaking out').

Houses in Wadeye are built quite close together, so that when heavy metal is played loudly in one house (or often, on the veranda of a house), it is audible to a large number of people in surrounding houses. This sort of metal 'broadcasting' occurs to a degree that would be considered socially unacceptable in most

31 Christie, Sound of the Beast, 49-55; Baulch, Making Scenes, 52-3.

32 Mansfield, 'The Social Organisation of Wadeye's Heavy Metal Mobs'. 
Australian towns, but although some older people at Wadeye have mentioned to me that they find it unpleasant, I have not observed anybody trying to intervene in another's music playing. This is quite consistent with a widely observed reluctance among Aboriginal people to constrain the behaviour of others. ${ }^{33}$ Late afternoon and evening - sometimes late into the night - are the main times for these metal broadcasts. No doubt this is because many kigay sleep for much of the day.

Playing metal music at high volume makes an aggressive demarcation of social space - by playing the music of one's ku spidi, one announces the presence of the associated metal mob. For example, kigay staying at the house adjacent to mine in Wadeye in 2012 were Tera mob, and they often played Pantera music loudly on their back porch. Other kigay visiting my house readily recognised this as Pantera music, and knew that this was the spidi of the kigay living in that house. Depending on context, the area around the house could be described as 'Tera area'. The association of ku spidi with particular parts of town is further demarcated by graffiti, as described below.

The playing of heavy metal music at Wadeye was undoubtedly first established as a loud public statement using home stereo equipment. This practice is still current, though there is now a second mode of audio reproduction. The use of mobile phones at Wadeye is now very widespread, though the manner in which this technology is used by kigay has some key differences with respect to urban Australian norms. The main difference between Wadeye phone usage and that of urban Australia is that phones in Wadeye are not as strongly attached to individual owners. Among close kin, phones regularly change hands, which radically affects their function as a communication technology. Kigay sometimes know which phone number should be used to reach a person; but much of the time there is no such reliable association, so kigay make phone calls by scrolling through the phone's recent call records and trying various numbers, connecting somewhat unpredictably to a range of kin, and with luck, heuristically approaching a connection with the target person-or at least gaining knowledge of their whereabouts. Text messages are not much used by kigay, due to limited literacy, though some formulaic messages are sent, such as 'CALL ME KREATOR', where the last part is the sender's ku spidi.

All phone models now have the capacity to store, exchange, and play back digital media in image, sound and video formats, and at Wadeye this aspect of the phone as a 'media device' is used to create a social network of digital exchange. The wandering of phones (not just 'mobile phones', but 'socially mobile phones') from person to person means that each phone accretes a collection of image, audio and video files that have been added by its various 
users. Since phones move between close kin, this collection tends to be a fairly coherent set of media with respect to socially symbolic ku spidi represented in songs and band images. Many other media genres are included in social phone networks, including Australian Football League team images, photographs of oneself and one's kin (sometimes with mob identifiers superimposed using image editing software on the phone, see Figure 1), pornography, and locally made videos that most often portray dancing or fighting. But the discussion here will be restricted to the heavy metal content.

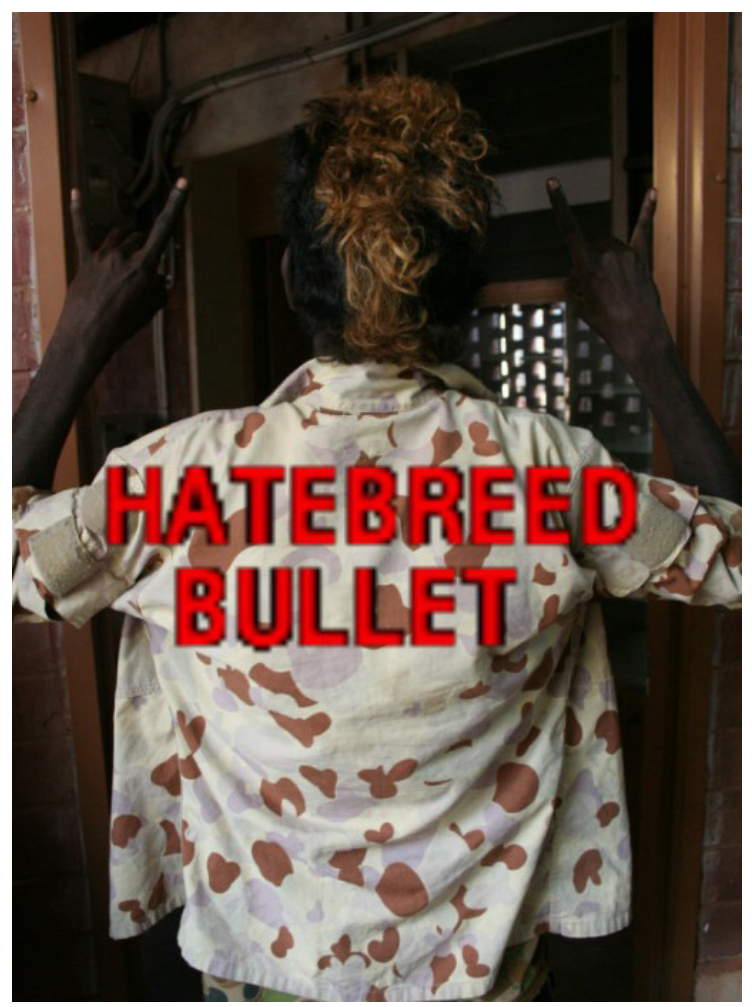

Figure 1: Mobile phone background image, created using image editing software on the phone.

Source: Used with permission of image creator, KM.

Phones have small, rather tinny speakers that allow songs to be played back. When I ask kigay about their mob affiliations, they will often not just tell me their affiliation, but demonstrate it by playing a sample of the ku spidi on their phone. This practice includes kigay who do not particularly like heavy metal music, but nonetheless carry it with them as a sort of digital badge representing social identity when required. Other kigay, who are more enthusiastic about the music, habitually play tracks on their phones as they walk around town. 
Phones move from person to person, while media files can be copied from phone to phone when in close physical proximity, using the Bluetooth file transfer protocol that operates wirelessly over short distances. ${ }^{34}$ Kigay are highly proficient in performing Bluetooth transfers, and just about any other of the myriad functions available on contemporary phones. This clearly requires some functionally specific literacy in being able to read menu options and file names, which contrasts with an extremely limited ability to write, either by pen or keyboard, in either English or Murrinhpatha. Many kigay struggle to write their names, though they may be more proficient writing the names of their ku spidi. ${ }^{35}$ The combination of Bluetooth file reproduction and the physical circulation of devices together creates a digital, social media network among kardu kigay. This is now the primary means by which heavy metal is circulated and 'performed' in Wadeye, and it is also a key technological basis for the expression of social relatedness.

It is evident that heavy metal music circulates very freely among related kigay via mobile phones, but there is something of a mystery as to how the mp3 files first enter this dense local network. The internet is the obvious suspect-but kigay generally have very limited access to computers. Home computers are non-existent among Aboriginal households in Wadeye, and though computers are available at the Wadeye library, most kigay seem uncomfortable entering this supposedly 'community' space. Occasionally some kigay do use the library, and when they do so, watching heavy metal videos via YouTube is one of their main goals. It may be that these kigay also download some metal musicthough I have never witnessed this, and it is not clear how many kigay have the computer proficiency to do so. Another possibility is that heavy metal sound files originally enter the Wadeye network via links with Aboriginal kin in larger urban centres, such as Katherine and Darwin, where perhaps there is greater internet access and proficiency. In any case, the key to the mystery of how such an internet-disconnected social group should have so much digital media circulating within it probably has to do with the minimal inputs required. With such dense social connectedness, and the infinite reproducibility of digital media, a particular heavy metal song or album only needs to be received once to be shared and reproduced widely within the local network.

\section{Drawing, Writing and Wearing Heavy Metal}

Heavy metal is not just a musical style, but also an associated graphic style, a particular vocabulary used in band names, song and album titles, and a fashion palette. The circulation of heavy metal at Wadeye includes not just the music

34 Jay Wyant, 'What Is Bluetooth?', Volta Voices 13:1 (2006): 54-5.

35 Kral, Plugged In. 
but also the graphic elements in the reproduction of written names, symbols and other imagery. Heavy metal band t-shirts are one mode in which such names and images circulate, being physically attached to kigay. In general, t-shirts worn by individuals correspond to ku spidi affiliations, but like mobile phones, clothing items circulate quite freely among kin, and occasionally this may result in kigay wearing t-shirts that do not reflect their own affiliations. The Judas Priest mob augment their metal fashion by wearing matching denim jackets emblazoned with ' $\mathrm{JP}^{\prime}$ ' badges. They are also visually distinguished as a mob by their preference for the 'mullet' hairstyle, though it is not clear whether this is directly inspired by metal bands.

Social signification is more intensive in the names and images that kigay reproduce themselves as graffiti. The walls of Wadeye are richly adorned with graffiti that is always focused on social identity, and never of the political or philosophical variety (for a while I thought that the graffito 'METAL UP YOUR

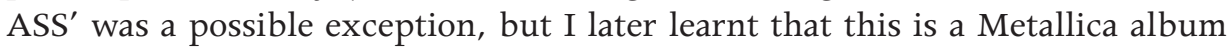
title). Graffiti is painted or drawn onto both public buildings and private houses, where it appears mostly on outside walls but also to some extent inside. Graffiti is often painted on road surfaces, benches, road-signs and any other markable public surfaces, including occasionally trees. Kigay sometimes use pen to draw names or insignia of their ku spidi on the skin of their arms, creating pseudotattoos - though I do not know of any kigay who has a real tattoo. Kigay's graffiti messages are almost exclusively declarations of social identity, either individual, or jointly declared by two or more kin. Here are some examples of individual declarations:

(1) GSW FEAR ON ME ${ }^{36}$

(2) EVIL TERA THATS ME GCYD ONLY TERA IN 2005

(3) EVIL DAVE LJMPMK

(4) SJKYDK G厅P FOREVER IN 2008

(5) BLACK LABEL SOCIETY 4 EVER ZAKK WYLDE 2007 4LIFE

Example (1) is a simple statement of Fear Factory affiliation by an individual represented as GSW. The next three examples include more elaborate individual initialisms: GCYD, LJMPMK and SJKYDK. These represent highly specified social identity, with initials representing both the European and Aboriginal names of the individual, as well as totem, initiation name, clan estate and other personally significant place names. Such matrices of individual identity are deliberately difficult to decode, and are recognisable only to fairly close kin.

36 All graffiti here is documented in the author's photographic collection, image numbers 4896, 4998, 5781, $5403,5452,5429$. 
Examples (2) and (3) include compound mob affiliations: Evil + Tera; Evil + Megadeth (represented obliquely by reference to Megadeth's lead guitarist, Dave Mustaine). Example (4) is probably a reference to German Punks (partially represented by the swastika, which is a graphic code for the German mob), or perhaps a compound reference to German + Priest. These mob encodings may be difficult to decipher for outsiders, but are universally understood by kigay.

Example (5) references a heavy metal band, Black Metal Society, which as far as I am aware does not have a mob associated with it. It also mentions the name of the band's lead guitarist, Zakk Wylde. I interpret this graffito to be a statement of personal musical taste, rather than a mob identifier; such a personal metal affiliation is sometimes described by the individual kigay as praibat ngay, 'my own (private) band metal'.

Here are some examples of jointly inscribed graffiti:

(6) MAD BOYS FF BFLN MTBD DBLM ANLP

\section{(7) LICA BIG T MRKTD STDWM OU2F}

Example (6) declares the relatedness of four kigay, and affiliates them as a group to the Mad Boys and Fear Factory (FF) mobs - though it leaves some ambiguity as to whether all four affiliate to both these mobs, or if some affiliate to one but not the other. Example (7) declares a joint affiliation to Lica (Metallica) and Big $\mathrm{T}$ (Testament), with the added code OU2F standing for 'only us two forever'. Such statements of apparent exclusivity (also present in example (2) above) are rather curious because they are clearly not statements of fact: GCYD is certainly not the 'only' affiliate of Tera, and in fact what his graffito affirms is relatedness to others. There is also plenty of Wadeye graffiti written by young women, which tends to focus more on romantic connections and other forms of social relatedness that are not expressed in terms of metal mobs - but the study of women's lifeworlds is beyond the scope of my research.

Finally, Wadeye metal graffiti is not limited to alphabetic names, but also includes various graphic devices, of which we have already seen one - the swastika. There are various other graphic symbols associated with various mobs, as shown in Figure 2. Most of these are copied from heavy metal album covers, though there is some innovation and experimentation in how these are reproduced.

\section{The Meaning of Heavy Metal in Wadeye}

In the previous section I described how heavy metal is circulated through social interactions and material technologies. In this section I will look more closely at two particular instances of social interaction to examine what these might 
tell us about the meaning of metal at Wadeye. This is by necessity rather more interpretive than the previous section, since meanings, concepts and ideas cannot be observed directly. However it is clear that cultural circulation is not just a matter of travelling artefacts, but also, perhaps more interestingly, the meanings that travel with them. ${ }^{37}$ Therefore it seems in order to make some comments here about what heavy metal might mean to kardu kigay.

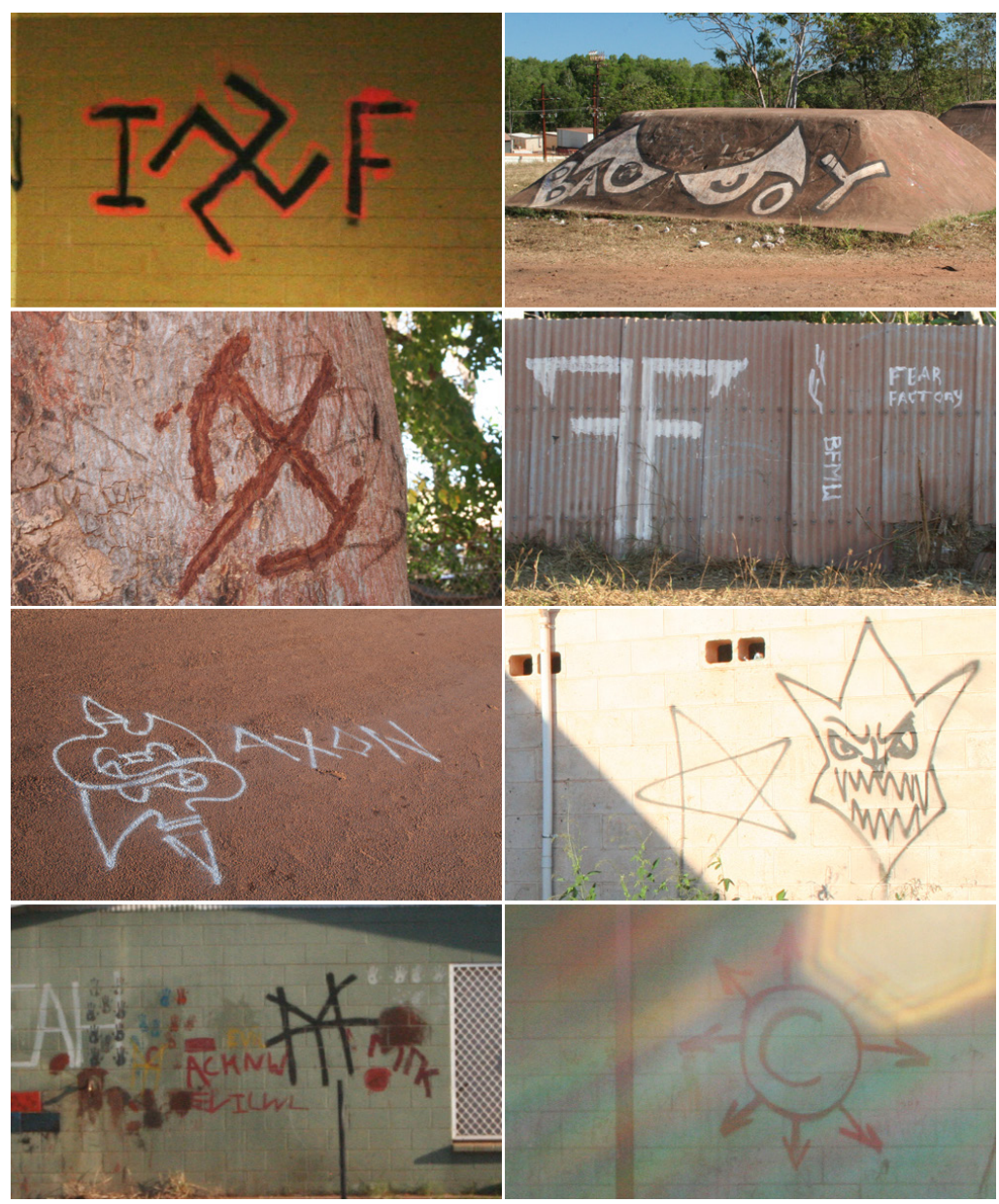

Figure 2: Graphic symbols of metal mobs, clockwise from top-left: German (swastika) + In Flames; Bad Boys (copied from a popular car sticker); Fear Factory (logo featured on album covers); Evil Warriors (devil image); Chimaria (logo featured on album covers); Machine Head (logo invented in Wadeye?); Saxon (logo featured on album covers); Judas Priest (device featured on album covers).

Source: All photos taken by the author during Wadeye fieldwork 2011-13. 


\section{Dancing With the Devil}

I take as my starting point a scene-in fact the climactic scene-from the documentary Heavy Metal Gangs of Wadeye ${ }^{38}$ Much of the film is not particularly informative - two young documentary makers from Melbourne visit Wadeye armed with a video camera, and spend a few days asking kigay a lot of direct questions, to which they predictably receive a lot of short answers like 'yes' and 'I don't know', and from which the film-makers reach their own conclusions. ${ }^{39}$ But the footage recorded in the climactic scene is quite fascinating: it shows kigay dancing as groups to their respective ku spidi at a nocturnal party. ${ }^{40}$ A stereo has been set up at a house, and floodlights create an illuminated dancefloor on the sand out the front. A series of heavy metal songs are played, each from a different metal band-Megadeth, Slayer, Exodus, etc. - and as each plays, affiliates of the relevant mob take to the dancefloor. The dance is a sort of whirlpool: a dozen kigay form a loose conglomerate that revolves counterclockwise, each kigay marching around, headbanging, occasionally raising a fist or playing air guitar.

This dance gathering is linked to two other dance practices at Wadeye. One involves a lighter style of rock music that is locally produced and sung in Murrinhpatha, with lyrics celebrating clan estates, and the totems and ancestors that reside there. ${ }^{41}$ The male dance practice for this also involves moving around in whirlpool formation, with the raised fists of the heavy metal dance replaced by a pointing action that signals the direction of the relevant clan estate. Men join such a dance for Country with which they have a kin-based relationship, much as the metal dance is joined by those who have a kin-based affiliation to the ku spidi.

An older form of dance is the ceremonial gathering in which traditional song genres djanba, wangga and lirrga are performed, accompanied by didjeridu and/ or clapsticks. ${ }^{42}$ This style of dance is also dedicated to clan estates, totems and ancestors, though the references are rather more elaborate and loaded with long traditions of sacred knowledge. ${ }^{43}$ The styles of dancing in these genres are often

\footnotetext{
38 Brooks and West, Heavy Metal Gangs of Wadeye.

39 I also find the methodology of the film to be ethically dubious, as many scenes appear to have been filmed without seeking permission, and kigay can be seen trying to hide their faces from the camera. Such practices promote the idea that whitefellas are intrusive and disrespectful.

40 Similar dances are reported in Furlan, Songs of Continuity and Change, 249; Bill Ivory, Kunmanggurr, Legend and Leadership (PhD, Charles Darwin University, 2009), 311.

41 Furlan, Songs of Continuity and Change.

42 See also Treloyn, this volume.

43 Linda Barwick 'Musical Form and Style in Murriny Patha Djanba Songs at Wadeye (Northern Territory, Australia)', in Analytical and Cross-Cultural Studies in World Music, eds Michael Tenzer and John Roeder (Oxford: Oxford University Press, 2011), 316-54; Linda Barwick, 'Marri Ngarr Lirrga Songs: A musicological analysis of song pairs in performance', Musicology Australia 28 (2006): 1-25; Allan Marett, Songs, Dreamings, and Ghosts: The wangga of north Australia (Middletown: Wesleyan University Press, 2005); Linda Barwick,
} 
mimetic of totemic natural species, though the whirlpool formation may also be performed for ragburning (mortuary) ceremonies. ${ }^{44}$ Again, the dance event is structured around various kin groups taking turns to dance according to the songs with which they have a relationship.

The 'heavy metal disco' of the documentary, then, is continuous with practices in which social groups use dance to invoke entities with which they have a symbolic relationship, and which empower the social groups through mystical consubstantiality with those entities. The social world is a highly structured network of related humans, with kinship operating throughout as a taxonomy of relationships, but the groups that are formed in this social world are also related to, or symbolised by, entities outside the social domain: natural species, sacred places, the spirits of the dead ... and heavy metal bands. The question naturally occurs, do ku spidi abide in the same domain as totems and ancestors? In general the answer is no, though heavy metal does invoke one Wadeye clan totem. When asking about heavy metal, I have more than once been told simply that it is music about ku karratj ('the devil'), and the Evil Warriors, once the largest and most fearsome mob in Wadeye, are said to have taken their name from $k u$ karratj, as some of their founding members belong to the clan for which this is a totem. ${ }^{45}$

The idea of the devil or some other dark power is a common motif in global heavy metal culture, ${ }^{46}$ and one which has clearly been adopted in Wadeye, though it is refracted through local cosmology. The syncretic melding of concepts clearly works both ways, as ku karratj has in turn taken up some European characteristics. For example, he is said to be covered in flames, and he lives in 'hell'. ${ }^{47}$

While traditional ceremony genres invoke totemic ancestors that guarantee the maintenance of the social order, listening to heavy metal invokes a power that is violent, chaotic and antisocial. Kigay have grown up in a milieu of great instability, typically witnessing incidents of violence and public disorder from a young age: 'kardu mamay ngatha, ngardiwerrerrdha, bamkardu kardu kura, kardu murlak, tju-mini mebatj pirrini tju litjpurr', 'when I was a child I was shaking (from fear), I saw drunken men, crazy men, when they fought they

\footnotetext{
Allan Marett, Joe Blythe and Michael Walsh, Arriving, Digging, Performing, Returning: An exercise in rich interpretation of a Djanba song text in the sound archive of the Wadeye knowledge centre, Northern Territory of Australia', in Oceanic Encounters: Festschrift for Mervyn McLean, ed. R.M. Moyle (Auckland: Research in Anthropology and Linguistics Monographs, 2007), 13-24.

44 Linda Barwick, personal communication.

45 There are alternative stories as to how the Evil Warriors got their name, but this is the one I find most convincing. The second part of the name is probably derived from The Warriors (1979), a dystopian film about gang wars in New York City.

46 Christie, Sound of the Beast, 240-75; Purcell, Death Metal Music.

47 Narrative recorded 1 September 2011. Video recording by Joe Blythe, transcription and translation by the author.
} 
would bring axes' ${ }^{48}$ Listening to metal is not an escape from these threats, but their embrace: finding power in chaos, transmuting fear into strength. One story tells of how a man now deceased, who is the grandfather of many Evil Warriors affiliates, once engaged $k u$ karratj in a fist fight, on the road out to Daly River. The man defeated ku karratj, and then 'pewa nukunu punirdirdi', 'his power went into them' - the man and his companions were miraculously transformed - 'a nakurl patha', 'and afterwards they felt good' ${ }^{49}$ Although it was one individual who defeated $k u$ karratj, his subversive power went into all of them: it was the whole group that was spiritually increased, or perhaps even the whole Evil Warriors mob. Similarly the dancing at the heavy metal disco is always a group activity.

The unity of brothers is another key concept among the metal mobs. This is often expressed using the word run, derived from English 'own', but used with a slightly different range of meaning that suggests both separation from others and strong internal unity. 'Runrun kem pigunu run Bullet, mu ngankunime run Kreator', 'they have their own Bullet mob, but we here have our own Kreator mob'. ${ }^{50}$ Heavy metal provides a neat symbol for this concept of brotherhood, since it is always a music of bands, not solo artists. The band is typically pictured together as a macho tableau on album covers, usually dressed similarly and often in poses that suggest they are fighting some sort of battle together. Walser identifies this masculine peer solidarity as 'the hero team', a key figure of heavy metal lyrics and imagery. ${ }^{51}$ It is through the unity of brothers (the metal mob, the hero team) that kigay find empowerment in chaos.

\section{Kardu Tjipmam and Ku Bamam}

The second incident I wish to explore involves a brief comment heard in passing, but one that points to some conceptual tensions. One day I was driving with three or four kigay from Wadeye to Ngarntimeli beach, DP in the front next to me, checking through the discs in the glove box, while others in the back asked about what sort of music was available. When somebody in the back asked if there was anything 'heavy', DP replied 'wurda, manangka music kardu tjipmam', 'no, there's no blackfella music'.

It was strange that DP referred to heavy metal as blackfella music, when all the band members of all the mobs' ku spidi are, without exception, ku bamam ('whitefellas'). But it is not inexplicable. I take it that DP sees metal as relating

\footnotetext{
48 CK, age 19, author's recording, 17 September 2011.

49 Conversation and narratives recorded 1 September 2011. Video recording by Joe Blythe, transcription and translation by John Mansfield.

50 Narrative recorded 1 September 2011. Video recording, transcription and translation by John Mansfield. 51 Robert Walser, Running with the Devil: Power, gender, and madness in heavy metal music (Middletown: Wesleyan University Press, 1993), 114.
} 
to blackfellas since in Wadeye all Aboriginal youth have ku spidi, and many actively enjoy the music, while whitefellas who live in Wadeye as teachers, doctors and other service workers in general listen to other popular genres. Wadeye has quite firm black/white social segregation, with much contact during the workday, but very little social engagement in people's free time. Even linguistically, kardu tjipmam (blackfella) and ku bamam (whitefella) fit into separate categories of the ten-part Murrinhpatha noun classification system: $k a r d u$ is the class of Aboriginal people, $k u$ is a class that includes whitefellas, animals, totems and various other spirit beings. Kigay often contrast themselves to whitefellas, pointing out differences such as shoe-wearing (whitefella) versus barefoot (blackfella), keeping one's tobacco to oneself (whitefella) versus sharing it freely among relatives (blackfella). There is a firm conceptual divide between the two types of people, and heavy metal falls clearly on the blackfella side.

But this doesn't explain away the fact that the metal bands, such an intense symbol of social identity among kigay, are all made up of whitefellas. Indeed, globally heavy metal is a very 'white' music genre. Non-white metal bands are remarkable by their absence, ${ }^{52}$ and some metal bands either subtly allude to or explicitly propose a white supremacist philosophy. ${ }^{53}$ Kigay seem either unaware of these connections or simply indifferent to them, and the same goes for use of the swastika as a symbol of the German mob, a very long-standing group which predates the arrival of heavy metal, and was named after Nazi villains seen in war movies - presumably not because of what they represented philosophically, but because they were identifiable as the 'bad guys' ${ }^{54}$

In concrete social interactions kigay have fairly superficial contact with whitefellas. Their school attendance and participation in formal work are both at very low levels, ${ }^{55}$ which leaves their interaction with whitefellas mostly limited to brief transactions at the shop or takeaway (notwithstanding the occasional linguist or ethnographer). But in their world of ideas, whitefellas figure prominently. The fact that the metal bands are all made up of whitefellas is not dismissed, but on the contrary is often referenced, as can be seen for example in the narrative fragment above - A crazy man, with long hair ... Who is this? A whitefella. This is a good song.' It is widely known that some of the bands, such as Kreator and Sodom, are more specifically ku german, 'Germans', which links them conceptually to the German mob, though Kreator at least is recognised as a separate mob. The kigay who make up the metal mobs are sometimes imaginatively figured in this vein, as gangs of $k u$. For example, in one story about

52 Christie, Sound of the Beast, 206.

53 Nicholas Goodrick-Clarke, Black Sun: Aryan cults, esoteric Nazism, and the politics of identity (New York: New York University Press, 2003).

54 Steve Bunk, 'Mixed Justice', The Bulletin, 6 September 1988.

55 John Taylor, Demography as Destiny: Schooling, work and Aboriginal population change at Wadeye (Canberra: CAEPR, 2010), 19, 34. 
a fight between the Lica mob and the Evil Warriors, the narrator adds colour by describing the two groups as ' $k$ u soldier' - 'two desperate armies', classified as $k u$ rather than $k a r d u$, facing off for battle. In another passing comment that caught my attention, at football training one evening the kigay were struggling to keep up with the fitness regime, and one joked out loud that they were ' $k u$ gengsta terert', 'all a bunch of gangsters' - the implication being that they spend their time smoking and fighting, rather than keeping fit. I found it curious that again, the kigay were classed as $k u$ in this humorous, imaginative reference. $K u$ versus kardu is a major grammatical distinction in Murrinhpatha, and I would argue, a deep conceptual distinction among people at Wadeye. The local social domain is classed as kardu, while animate entities foreign to this are $k u$. Of course kigay are kardu, but they sometimes imagine themselves as $k u$.

Kigay perceive that whitefellas have a certain capacity for rebellion, freedom and licentiousness, and the appeal of these images goes back to well before heavy metal. Furlan records memories of 1970s Wadeye motorbike gangs, in which the kigay of the day wore 'proper whitefella boots, gloves and scarfs' ${ }^{56}$ Heavy metal is a more recent cultural resource that feeds into imaginative play with the $k a r d u / k u$ dichotomy. This is somewhat reminiscent of an exchange Musharbash records with a seventeen-year-old Warlpiri girl: when asked what she would do with a million dollars, she says she would build herself a big house, with lots of rooms, each furnished, and with televisions, stereos, video players and Playstations. But no-one else would be allowed to live there, she would live in the house alone. ${ }^{57}$ The girl's wish is clearly for an autonomy that is hard to find in the densely related world of an Aboriginal community. But further, I wonder if this is how she imagines that whitefellas live? For Wadeye kigay, the consumer goods and luxurious houses of whitefellas seem to hold only a limited appeal, but what really captures their imagination is the wildness and freedom of whitefella rebel figures, young men like themselves who spurn all authority and make their own rules.

\section{Conclusion}

Listening to heavy metal at Wadeye is paradoxical in that it affirms and reproduces highly localised forms of social interaction, while connecting people both materially and imaginatively with a globalised genre of cultural production. The artefacts of this global circulation trickle in to Wadeye via fairly narrow channels of cultural contact - cassettes, CDs, mp3 tracks and t-shirts - but little

56 Furlan, Songs of Continuity and Change, 221.
57 Musharbash, Yuendumu Everyday, 1. 
or no direct social connections with any external heavy metal 'scene'. However, once heavy metal artefacts reach Wadeye, they are intensively circulated through kin networks.

Being such an important cultural resource for kardu kigay, the meanings of heavy metal at Wadeye are complex, manifold, and undoubtedly vary greatly from one individual to another. However, I have tried to identify some major threads of meaning, describing how social practices relate metal to concepts of evil, chaos, subversion, power, brotherhood, solidarity, whitefellas and blackfellas.

In this chapter I have aimed to contribute to our understanding of the Aboriginal reception of mass media, and to show how an ethnographic approach can enrich such a study. There is great scope for further research in this field; for example, a study of Aboriginal film viewing, which has a history going right back to mission days, might prove fascinating. Television provides another more recent media stream for investigation, and in communities where English is not the main language, raises some interesting questions about cross-linguistic media reception. Further research might also be done on young Aboriginal people's use of popular music genres; and this should include hip-hop, for although it has already been investigated to some extent, there is not yet any ethnographic account of how Aboriginal people engage with hip-hop, nor how this engagement might differ between urban communities and those in the desert. Such research would not be constrained within the discipline of 'media studies', but rather would contribute to a broader project that analyses how culture circulates or diffuses from one place to another. The relatively recent contact of radically different cultures in central and northern Australian provides particularly rich material for such a project.

\section{Acknowledgements}

My field research for this chapter is heavily indebted to DP, LP and KM, as well as financial support from Thamarrurr Development Corporation, Wadeye. Invaluable comments were provided by Amanda Harris, and two anonymous reviewers. 


\section{References}

Altman, John. Hunter-Gatherers Today: An Aboriginal economy in northern Australia (Canberra: Aboriginal Studies Press, 1987).

Altman, John, and Melinda Hinkson. 'Mobility and Modernity in Arnhem Land: The social use of Kuninjku trucks', Journal of Material Culture 12:2 (2007): 181-203.

Appadurai, Arjun. Modernity at Large: Cultural dimensions of globalization (Minneapolis: University of Minnesota Press, 1996).

Barwick, Linda. 'Musical Form and Style in Murriny Patha Djanba Songs at Wadeye (Northern Territory, Australia)', in Analytical and Cross-Cultural Studies in World Music, eds Michael Tenzer and John Roeder (Oxford: Oxford University Press, 2011), 316-54.

Barwick, Linda. 'Marri Ngarr Lirrga Songs: A musicological analysis of song pairs in performance', Musicology Australia 28 (2006): 1-25.

Barwick, Linda, Allan Marrett, Joe Blythe, and Michael Walsh. 'Arriving, Digging, Performing, Returning: An exercise in rich interpretation of a Djanba song text in the sound archive of the Wadeye knowledge centre, Northern Territory of Australia', in Oceanic Encounters: Festschrift for Mervyn McLean, ed. R.M. Moyle (Auckland: Research in Anthropology and Linguistics Monographs, 2007), 13-24.

Baulch, Emma. Making Scenes: Reggae, punk, and death metal in 1990s Bali (Durham: Duke University Press, 2007).

Bell, Wendy. A Remote Possibility: The battle for Imparja television (Alice Springs: IAD Press, 2008).

Brady, M. Heavy Metal: The social meaning of petrol sniffing in Australia (Canberra: Aboriginal Studies Press, 1992).

Brooks, Hannah, and Jonathan West. Heavy Metal Gangs of Wadeye (VBS, 2009).

Bunk, Steve. 'Mixed Justice', The Bulletin, 6 September 1988.

Christie, Ian. Sound of the Beast: The complete headbanging history of heavy metal (New York: Harper Collins, 2003).

Dawes, Glenn. 'Figure Eights, Spin Outs and Power Slides: Aboriginal and Torres Strait Islander youth and the culture of joyriding', Journal of Youth Studies 5:2 (2002): 195-208. 
Deger, Jennifer. Shimmering Screens: Making media in an Aboriginal community (University of Minnesota Press, 2006).

Furlan, Alberto. Songs of Continuity and Change: The reproduction of Aboriginal culture through traditional and popular music (PhD, University of Sydney, 2005).

Geertz, Clifford. The Interpretation of Cultures (New York: Basic Books, 1973).

Goodrick-Clarke, Nicholas. Black Sun: Aryan cults, esoteric Nazism, and the politics of identity (New York: New York University Press, 2003).

Hannerz, Ulf. Transnational Connections: Culture, people, places (London: Routledge, 1996).

Ivory, Bill. Kunmanggurr, Legend and Leadership (PhD, Charles Darwin University, 2009).

Kral, Inge. Plugged in: Remote Australian Indigenous youth and digital culture (Canberra: CAEPR, 2010).

Krenske, Leigh, and Jim McKay. "Hard and Heavy": Gender and power in a heavy metal music subculture', Gender, Place and Culture 7:3 (2000): 287-304.

Magowan, F. 'Faith and Fear in Aboriginal Christianity', in Aboriginal Religions in Australia: An anthropology of recent writings, eds M. Charlesworth, Francoise Dussart, and Howard Morphy (Aldershot: Ashgate, 2005), 279-96.

Mansfield, John. 'The Social Organisation of Wadeye's Heavy Metal Mobs', The Australian Journal of Anthropology 24:2 (2013): 148-65.

Marett, Allan. Songs, Dreamings, and Ghosts: The wangga of north Australia (Middletown: Wesleyan University Press, 2005).

Martin, David Fernandes. Autonomy and Relatedness: An ethnography of Wik people of Aurukun, Western Cape York Penninsula (PhD, The Australian National University, 1993).

McKnight, David. From Hunting to Drinking: The devastating effects of alcohol on an Australian Aboriginal community (London: Routledge, 2002).

Michaels, Eric. The Aboriginal Invention of Television in Central Australia, 19821986 (Canberra: Australian Institute of Aboriginal Studies, 1986).

Michaels, Eric. 'Hollywood Iconography: A Warlpiri reading', in Second International Television Studies Conference, 1986, eds Phillip Drummond and Richard Patterson (London: BFI Publishing, 1988). 
Mitchell, Tony. 'Blackfellas Rapping, Breaking and Writing: A short history of Aboriginal hip-hop', Aboriginal History 30 (2006): 124-37.

Molnar, Heather, and Michael Meadows. Songlines to Satellites: Indigenous communication in Australia, the South Pacific and Canada (Sydney and Wellington: Pluto Press and Huia Publishers, 2001).

Morgan, George, and Andrew Warren. 'Aboriginal Youth, Hip Hop and the Politics of Identification', Ethnic and Racial Studies 34:6 (2011): 925-47.

Murdoch, Lindsay. 'Hate Stalks a Community Where Gangs Rule Roost', The Age, 23 May 2006.

Murphy, David Jo. Hate Couture: Subcultural fundamentalism and the Serbian black metal scene (PhD, NUI Maynooth, 2011).

Musharbash, Yasmine. Yuendumu Everyday: Contemporary life in a remote Aboriginal settlement (Canberra: Aboriginal Studies Press, 2008).

Ottosson, Ase. 'The Intercultural Crafting of Real Aboriginal Country and Manhood in Central Australia', The Australian Journal of Anthropology 23 (2012): 179-96.

Pennycook, Alastair, and Tony Mitchell. 'Hip Hop as Dusty Foot Philosophy: Engaging locality', in Global Linguistic Flows: Hip hop cultures, youth identities and the politics of language, eds H. Samy Alim, Awad Ibrahim, and Alistair Pennycook (New York: Routledge, 2009), 25-42.

Peterson, Nicolas. 'Cash, Commoditisation and Authenticity: When do Aboriginal people stop being hunter-gatherers? In Cash, Commoditisation and Changing Foragers, eds Nicolas Peterson and Toshio Matsuyama (Osaka: National Museum of Ethnology, 1991), 67-90.

Purcell, Natalie J. Death Metal Music: The passion and politics of a subculture (Jefferson: McFarland \& Company, 2003).

Pye, Br John MSC. The Port Keats Story (Darwin: Colemans, 1972).

Sansom, Basil. The Camp at Wallaby Cross: Aboriginal fringe dwellers in Darwin (Canberra: Australian Institute of Aboriginal Studies, 1980).

Sansom, Basil. 'A Grammar of Exchange', in Being Black: Aboriginal cultures in 'settled' Australia, ed. Ian Keen (Canberra: Australian Institute of Aboriginal Studies, 1988), 159-78.

Schwarz, Carolyn, and Francoise Dussart. 'Christianity in Aboriginal Australia Revisited', The Australian Journal of Anthropology 21 (2010): 1-13. 
Sutton, Peter. 'Aboriginal Spirituality in a New Age.' The Australian Journal of Anthropology 21 (2010): 71-89.

Taylor, John. Demography as Destiny: Schooling, work and Aboriginal population change at Wadeye (Canberra: CAEPR, 2010).

Tonkinson, R. 'Reflections on a Failed Crusade', in Aboriginal Australians and Christian Missions, eds T. Swain and Deborah Bird Rose (Bedford Park: Australian Association for the Study of Religions, 1988), 60-73.

Toohey, Paul. 'Gangsters' Paradise', Bulletin, 10 February 2004.

Waksman, Steve. This Ain't the Summer of Love: Conflict and crossover in heavy metal and punk (Berkeley: University of California Press, 2009).

Walser, Robert. Running with the Devil: Power, gender, and madness in heavy metal music (Middletown: Wesleyan University Press, 1993).

Wyant, Jay. 'What Is Bluetooth?', Volta Voices 13:1 (2006): 54-5. 
This text taken from Circulating Cultures: Exchanges of Australian Indigenous music, dance and media, edited by Amanda Harris, published 2014 by ANU Press, The Australian National University, Canberra, Australia. 